http://doi.org/10.35784/iapgos.2081

\title{
INCREASING RADIATION RESISTANCE OF MEMORY DEVICES BASED ON AMORPHOUS SEMICONDUCTORS
}

\author{
Vasyl Kychak, Ivan Slobodian, Victor Vovk \\ Vinnytsia National Technical University, Faculty of Information Communication, Radio Electronics and Nanosystems, Vinnytsia, Ukraine
}

Abstract. A memory cell structure is proposed that uses a Schottky barrier thin film transistor based on an amorphous semiconductor as a junction element, and a chalcogenide glassy semiconductor film as a switching element. A physical storage cell model has been developed. The dependence of the transistor and memory cell parameters on the dose of neutron flux and $\gamma$-quanta was investigated. It is shown that when the dose of neutron irradiation is changed, the steepness of the drain-gate characteristic (DGC) decreases by $10 \%$ at a dose of the order of $10^{15} \mathrm{n} / \mathrm{s}$, and at the same time, the transfer coefficient of the bipolar n-p-n transistor decreases by $20 \%$ at doses of $10^{13} \mathrm{n} / \mathrm{s}$, indicating a significant increase in the radiation resistance of the proposed memory cell. In the case of irradiation with $\gamma$-quanta in the range up to 2.6 MRad, the steepness of the DGC of the proposed structure changes by only 10\%. When used as an isolation element, a field-effect transistor with an insulated gate, the slope of the DGC is reduced by 50\%. It is shown that the current of recording information of the proposed structure when changing the dose of $\gamma$ - quantum flux to 2.6 MRad changes by about $10 \%$, and at the same time, in the case of using a field-effect transistor with an isolated cover, the information recording current changes by 50\%. The study of the dependence of the gate current on the dose of the $\gamma$-quanta is shown. When the radiation dose changes from 0 to 2.6 MRad, the gate current changes only by $10 \%$, which indicates the high resistance of the proposed structure to the action of permeable radiation. Also, studies of the dependence of the conductivity of single-crystal semiconductors on a radiation dose y by quanta and neutron flux show that a significant increase in the specific resistivity of amorphous semiconductors occurs at doses 2-3 orders of magnitude larger than in the case of single-crystal n-type conductivity semiconductors.

Keywords: amorphous semiconductor, chalcogenide glassy semiconductors, radiation resistance, memory cell

\section{ZWIĘKSZENIE ODPORNOŚCI NA PROMIENIOWANIE URZĄDZEŃ PAMIĘCIOWYCH W OPARCIU O PÓŁPRZEWODNIKI AMORFICZNE}

Streszczenie. Zaproponowano strukturę komórki magazynującej, która wykorzystuje barierowy cienki tranzystor Schottky'ego oparty na pótprzewodniku amorficznym jako element łaczacy, a także chalkogenowa szklista błone pótprzewodnikowa jako element przełaczajacy. Opracowano fizyczny model komórki pamięci. Zbadano zależność parametrów tranzystora i komórki pamięci od dawki strumienia neutronów i promieni gamma. Pokazano, że przy zmianie dawki napromieniowania neutronowego stromość charakterystyki odpowiedzi drenu zmniejsza się o $10 \%$ przy dawkach rzędu $10^{15}$ n/s, a jednocześnie współczynnik przenoszenia bipolarnego tranzystora npn spada o $20 \%$ już przy dawkach $10^{13}$ n/s, wskazując znaczny wzrost odporności na promieniowanie proponowanej komórki pamięci. Po napromieniowaniu kwantami gamma w zakresie do 2,6 MRad stromość charakterystyki drenprzepustnica proponowanej konstrukcji zmienia się tylko o $10 \%$. W przypadku połaczenia jako cienkowarstwowego tranzystora polowego z izolowana kurtyna charakterystyka stromego spadku zmniejsza się o 50\%. Wykazano, że prad zapisu informacji o proponowanej strukturze przy zmianie dawki strumienia kwantowego gamma na 2,6 MRad zmienia się o około 10\%, przy jednoczesnym zastosowaniu cienkowarstwowego tranzystora polowego z izolowana ostona, prad zapisu informacji zmienia sie o 50\%. Badanie zależności pradu kurtynowego od dawki promieniowania gamma - kwanty. Gdy dawka promieniowania zmienia się od 0 do 2,6 MRad, prąd kurtyny zmienia się tylko o 10\%, co wskazuje na wysoka odporność proponowanej struktury na działanie promieniowania przepuszczalnego. Badania zależności przewodności pótprzewodników monokrystalicznych od dawki promieniowania $\gamma$ przez kwanty i strumień neutronów pokazuja, że znaczny wzrost rezystywności właściwej pótprzewodników amorficznych wystęuje przy dawkach 2-3 rzędów wielkości większych niż w przypadku półprzewodników przewodnictwa monokrystalicznego typu n.

Słowa kluczowe: półprzewodnik amorficzny, półprzewodniki szkliste chalkogenowe, odporność na promieniowanie, komórka pamięci

\section{Introduction}

An important prerequisite for the design of radio electronic systems for military and space purposes is the provision of high resistance to penetrating radiation, ionizing radiation and other external influences $[1,8]$.

It is known that under the influence of penetrating radiation on semiconductor electronic components made on the basis of singlecrystal semiconductors, a large number of defects are produced which increase the electrical conductivity, which leads to their destruction $[2,10]$.

In the case of amorphous semiconductors (AS), where there is a large degree of disordering of the atoms, the action of penetrating radiation does not significantly affect their electrical conductivity, and therefore provides high radiation resistance, which exceeds by $2-3$ orders of magnitude the radiation resistance of components on the basis of single crystal semiconductor [9, 11].

In [3], a nonvolatile chalcogenide glassy semiconductor (CGS) storage device is proposed, which is a connection of a switch element on the basis of CGS and a decoupling element implemented on the basis of a unipolar transistor with an isolated gate. There are suggested as ways to increase the radiation resistance of the element.

However, the proposed methods for increasing the radiation resistance of a unipolar transistor junction provide the same results as for dielectric insulated bipolar transistors [6]. Therefore, it is advisable to develop structures that would significantly improve radiation resistance.
In this regard, the purpose of this work is to develop a memory cell structure in which the switching element and the junction element are made on the basis of AS, which makes it possible to increase the radiation resistance, and to investigate its effect on the steepness of the drain-gate characteristic (DGC) thin-film FET, recording current and reading information.

\section{Development of structure and physical model of a memory cell based on AS}

The structure of an elementary storage device (memory cell) which use a thin film transistor with a Schottky gate based on AS as a switching element-CGS, and as a decoupling element - is shown in Fig. 1.

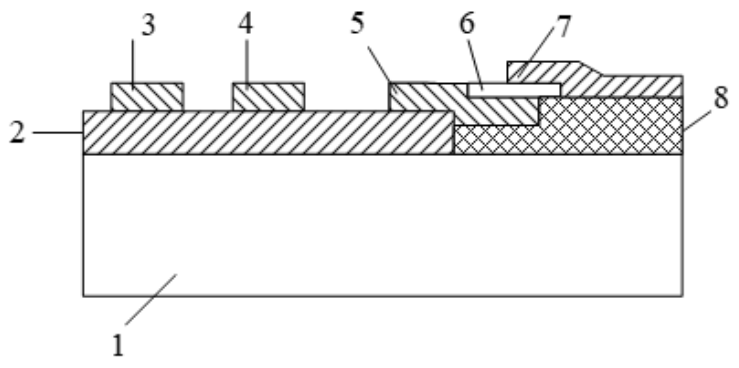

Fig. 1. Structure of a memory cell based on AS 
The memory cell is a transparent substrate 1 of glass, on the surface of which is deposited a layer of AS 2, part of which is etched to produce local oxidation, resulting in the formation of a film of silicon dioxide 8 . An electrode of source 3 , gate 4 and drain 5 is then formed on the surface of the AS film. The drain electrode is partially placed on the surface of the silicon dioxide 8 . After the formation of the electrodes, there is a local extension of CGS film 6 on the surface of part of the drain electrode (information recording electrode). In the next step, a CGS 7 electrode (information readout electrode) is formed. Molybdenum layers are used to make the electrodes of the field-effect transistor and the CGS film. This provides a reduction in the threshold voltage of the FET and reliable contact with the CGS film.

The peculiarity of the structure of the storage device (SD) is the use of the thin-film transistor as an element of the junction, in which the Schottky barriers are formed at the boundary of the distribution of the metal gate, source and drain with the amorphous semiconductor (AS).

It is advisable to construct a physical model of the structure shown in Fig. 1 for evaluating the parameters and characteristics of an AS-based storage device. The physical model shall reflect an equivalent circuit of a thin-film transistor, its structural features, and an equivalent circuit of a switch element based on AS. With this in mind, the physical model of the elementary storage device is shown in Fig. 2.

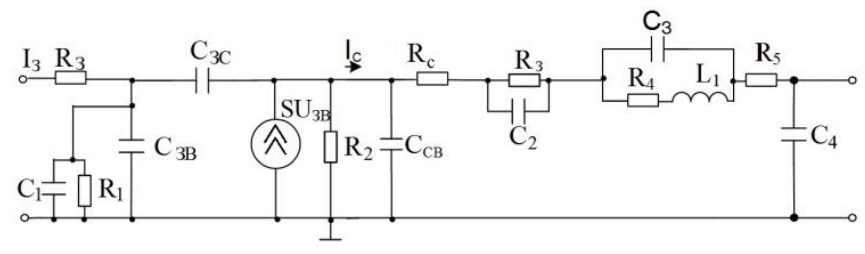

Fig. 2. Physical model of the elementary storage device

In Fig. 2, where $R_{3}-$ the resistance of the molybdenum curtain electrode; $C_{I}$ i $R_{l}$ - the capacitance and resistance of the Schottky transition gate; $C_{3 B}$-the input capacity of the transistor; $C_{3 C}$ - the transistor throughput capacity; $S$ - the steepness of the drain-gate characteristic; $C_{C B}$ - the output capacitance of the transistor; $R_{C}$ - the resistance of the molybdenum drain electrode; $R_{2}$ - the dynamic resistance of the transistor; $R_{4}, C_{3}, L_{1}-$ the resistance, capacitance and inductance of the equivalent circuit of the switching element based on AS; $R_{5}-$ the Schottky drain resistance; and $C_{4}$ - the electrode drain capacity.

\section{Research on storage devices based on CGS}

The main parameters of the storage device (SD) are the current flowing through the SD in the log mode "1", the current flowing in the read mode, the resistance in the low-ohm state, which corresponds to the logical "1" and the resistance in the high-ohm state, which corresponds to the logical "0". In order to calculate these parameters, it is necessary to determine the currents that must flow through the junction element in the respective modes.

The dependence of the transistor drain current on the voltage on the drain and the gate is determined by the expression in [12]:

$$
\mathrm{I}_{\mathrm{C}}=\frac{Z \mu_{n} C_{1}}{l}\left\{\begin{array}{c}
\left(U_{3 \mathrm{~B}}+2 \varphi_{\mathrm{B}}-\frac{U_{\mathrm{CB}}}{Z}\right) U_{\mathrm{CB}}-\frac{2}{3} \frac{\sqrt{2 \varepsilon N_{a}}}{\mathrm{C}} \\
\left\lceil\left(U_{\mathrm{CB}}-2 \varphi_{\mathrm{B}}\right)^{3 / 2}-\left(2 \varphi_{\mathrm{B}}\right)^{3 / 2}\right\rceil
\end{array}\right\}
$$

where $Z, l$-the width and thickness of the channel, $\mu_{n}$-the mobility of the charge carriers, $C_{1}$ - the specific capacitance of the AS transition-the gate, $\varepsilon$ - the dielectric constant of the AS film, $\varphi_{\mathrm{B}}$ - the value of the built-in potential, and $N_{a}$ - the concentration of charge carriers in the AS film.

In our case, the drain current determines the current flowing through the memory element in logical mode "1". When reading the information, the impulse is applied to the gate of the transistor.
The value of the gate current can be calculated using the expression for the CVC of the metal contact with the AS film [5].

$$
j_{3}=j_{0}\left(e^{g U_{3 \mathrm{~B}} / \mathrm{KT}}-1\right)
$$

where $j_{0}$ - the density of the extraction current, the value of which can be calculated by the expression:

$$
j_{0}=A N_{c} D_{n} g_{0} \sqrt{B} \frac{\exp -g U_{b n} / K T}{1-\exp (-A)}
$$

where $A=\frac{0.77 g\left(\varphi_{\mathrm{B}}-U_{\mathrm{B}}\right)}{K T}, B=\frac{e^{2} g}{\varepsilon \varepsilon_{0} \varphi_{\mathrm{B}}}, N_{C}$ - the density of states at the energy level with energy $E_{C}, \varphi_{\mathrm{B}}$ - the magnitude of the built-in potential, $D_{n}$ - the electron diffusion coefficient, $g_{0}$ - the density of localized states, and $U_{b n}$ - the height of the Schottky barrier.

The most important parameter of a field-effect transistor, which is affected by neutron irradiation, is the DGC steepness. Experimental studies show that the value of the DGC steepness is related to the neutron flux by the following ratio:

$$
\frac{1}{S}=\frac{1}{S_{0}}-\frac{\tau_{K}}{k}
$$

where $\tau_{K}$-the passage time of charge carriers of the channel, $\phi$-neutron flux $\left(N^{0} / \mathrm{cm}^{2}\right)$, and $k$-a constant, which is determined experimentally.

Using expression (4), the dependence of the DGC steepness on the neutron flux dose can be determined by the expression:

$$
S=\frac{S_{0} K}{K+\tau_{0} \phi S_{0}}
$$

The calculations used the following input data: $\tau_{K}=10^{-10} S$, the proportionality factor, which is a function of many parameters, is assumed to be $\phi=10^{6} \mathrm{~N}^{0} / \mathrm{c} \cdot \mathrm{cm}^{2}$.

The dependence of the steepness of the DGC on the dose of neutron irradiation is shown in Fig. 3.

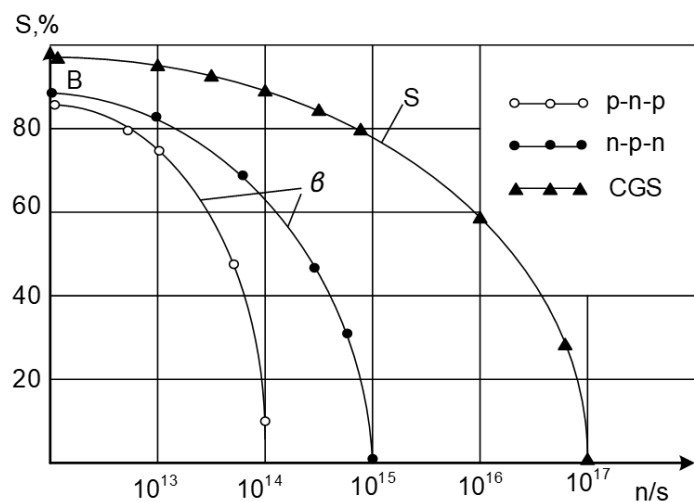

Fig. 3. Dependence of the CCS steepness and transmission coefficient $b$ on the neutron flux dose

Fig. 3 is a graph of the current transfer coefficient $b$ for bipolar n-p-n and p-n-p transistors [10]. Comparison of these transistors demonstrates that at doses greater than $10^{13} \mathrm{n} / \mathrm{s}$, the transfer coefficient of the bipolar transistor decreases substantially, and the DGC steepness of a thin-film transistor based on AS sharply decreases only at doses on the order $10^{16} \mathrm{n} / \mathrm{s}$.

An analysis of the expression for the drain current (1), which determines the recording current of the logical "1" shows that its value depends on the mobility of charge carriers and the charge concentration on the surface of the AS, or the density of the surface states. Therefore, it is advisable to evaluate the dependence of the density of the surface states and the mobility of the charge carriers on the irradiation dose. For single-crystal semiconductors, the dependence of the density of the surface states on the radiation dose by $\gamma$-quanta is determined by the expression in [5]

$$
N_{C}(D)=N_{c}^{l}\left(1-\exp -\frac{D}{D_{m}}\right)
$$


where $N_{c}^{l}$ - the density of the surface states when the transistor is in saturation mode, and $\frac{1}{D_{m}}-$ the rate of charge accumulation on the surface of the AS.

Unlike thin-film field-effect transistors with insulated shields, the processes of changing the surface states at the interface of the sub-gate layer - semiconductor, which is one of the main ones which significantly affect the parameters of the transistor under irradiation, are not taken into account here.

In [7], it is shown that the mobility of the charge carriers of CGS is much lower than the mobility of charge carriers in singlecrystal semiconductors, and therefore the rate of charge accumulation on the surface of the AS will be much lower, and accordingly, the action of irradiation will be manifested here at higher doses. The dependence of the charge carrier mobility on the irradiated dose can be calculated by an expression similar to (4):

$$
\mu=\frac{\mu_{0}}{1+\gamma \cdot N_{C}^{l} \cdot\left(1-\exp \frac{D}{D_{m}}\right)}
$$

where $\mu_{0}$-the mobility of the charge carriers in the absence of irradiation; and $\gamma$ - the proportionality factor.

In estimating the dependence of the DGC steepness on the action of irradiation by $\gamma$-quanta, it was taken into account that, unlike conventional MOS transistors, where significant changes occur due to charge accumulation in the volume of the sub-gate dielectric layer, in the case of a thin-film FET, there is a change of surface states at the boundary of the AS distribution - metal. Since there is a significant disordering of atoms in AS, this change is insignificant. At high doses, the surface states that are formed lead to the scattering of charge carriers in the channel and to a decrease in their mobility.

Due to this, the threshold voltage will be changed and the steepness of the DGC will decrease, as well as the informationrecording current.

Fig. 4 shows the dose dependence of the steepness of the DGC, the recording current of the logical "1" and the gate current from the $\gamma$-quanta irradiating dose. For comparison, these graphs show similar dependencies of the same parameters for a conventional MOS transistor, taken from [5]. An analysis of the results shows that as the dose is increased, the steepness of the DGC of a thin-film FET based on AS changes to insignificant limits (up to 10\%), while, in the case of traditional MOS transistors, it decreases by almost twice as much. Similarly, the drain current (logic entry "1") increases for the AS-based transistor by about $10 \%$, and for the traditional MOS transistor almost twice as much. Such a course of characteristics is caused by the fact that under the action of $\gamma$ irradiation, in the case of traditional MOS transistors, the density of the surface states increases at the interface of the dielectric - semiconductor, and there is a charge accumulation in the volume of the sub-gate layer dielectric.

In the case of an AS-based transistor, there is a slight charge accumulation only at the metal-AS interface, and the mobility of the charge carriers is much lower so a significant increase in current and a decrease in the steepness of the DGC do not occur at relatively small doses.

The gate current changes little with an increasing dose. The slight increase is due to the fact that there is an increase in the density of the localized state, which is partially offset by a decrease in the mobility of the charge carriers and the diffusion coefficient, the dependence of which on the irradiation dose is determined by an expression similar to (5).

The following initial data were used in the calculations: $l=4 \mu \mathrm{m}, \quad Z=2 \mu \mathrm{m}, \quad C_{l}=1 \mathrm{pF}, \quad \varepsilon=3, \quad N_{C}=10^{15} \frac{1}{\mathrm{~cm}^{3}}$, $N_{a}=10^{8} \frac{1}{\mathrm{~cm}^{3}}, \quad g_{0}=10^{17} \mathrm{eV}^{-1} \mathrm{~cm}^{-3}, \quad \mu_{0}=4 \cdot 10^{-2} \frac{\mathrm{cm}^{2}}{\mathrm{~V} \cdot \mathrm{s}}, \quad$ and $\gamma=10^{6} \frac{\underset{\mathrm{n}}{\mathrm{cm}^{3}}}{\mathrm{~s} \cdot \mathrm{cm}^{2}}$.

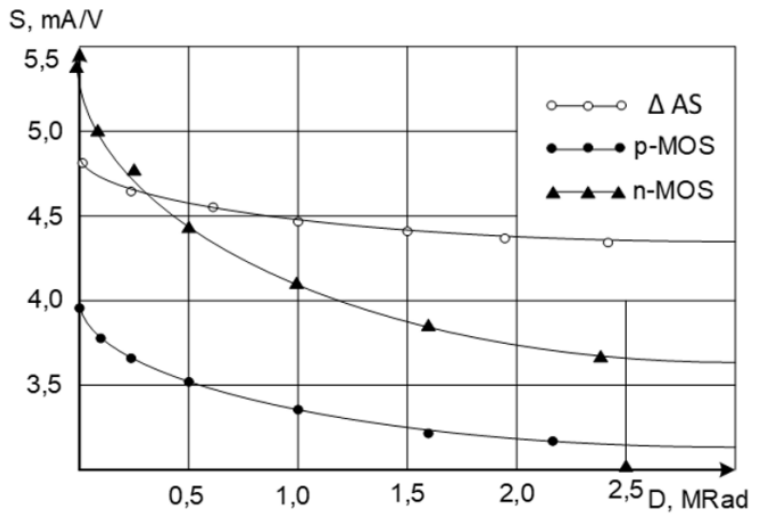

a)

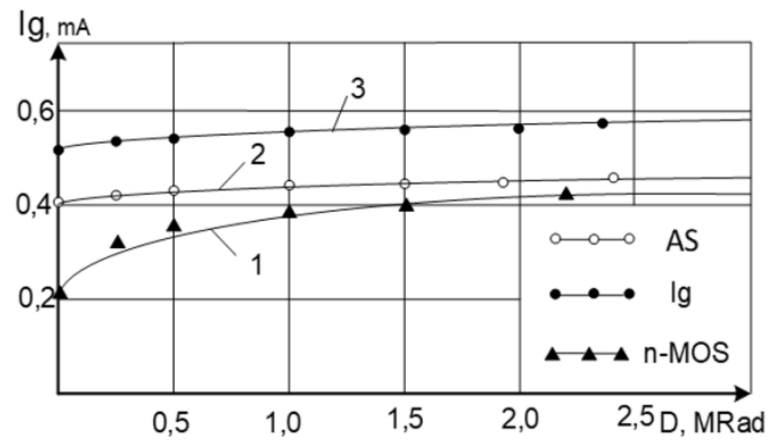

Fig. 4. Dependence of the steepness of the DGC (a) and the recording current "I" and the gate current (b) on the dose of $\gamma$-quanta

Only the dependence of the density of the surface states and the mobility of the charge carriers on the irradiation dose was taken into account.

Studies of the dependence of the conductivity of single-crystal semiconductors on the dose of $\gamma$-quanta and neutron flux, performed by several authors, show that the change in conductivity occurs at doses of the order of $10^{5} \mathrm{Mrad} / \mathrm{s}$ and $10^{16} \mathrm{n} / \mathrm{s}$. In the case of $\mathrm{AS}$, the dependence of electrical conductivity on the radiation dose can be determined by the expression in [4]:

$$
\sigma(E, D)=\sigma(D) \exp \left(\frac{e \cdot a \cdot E}{k T}\right)
$$

where $\sigma(D)$ - the dependence of the electrical conductivity on the radiation dose in the absence of electric field strength, and $\mathrm{a}-$ the distance between the localized states.

The dependence of the electrical conductivity on the radiation dose taking into account (6) and (7) can be calculated by the expression:

$$
\begin{gathered}
\sigma(D)=e \cdot N_{c}(D) \cdot \mu(D)= \\
=e \cdot N_{c}\left(1-\exp \frac{D}{D_{m}}\right) \cdot\left(\frac{\mu 0}{1+\gamma \cdot N^{`} c\left(1-\exp \left(\frac{D}{D_{m}}\right)\right.}\right)
\end{gathered}
$$

Using (9) and the expression for the specific resistance given in [4], we can investigate the dependence of the specific resistance of a memory cell based on CGS on the radiation dose and the electric field intensity:

$$
\rho(D, E)=\frac{g \cdot C_{1} \Delta T}{\sigma^{2}(D) \cdot \exp \left(\frac{2 e \cdot a \cdot E}{k T}\right) E^{2}}
$$

where $g$ - the sample density, $C_{1}-$ the specific heat capacity of CGS, and $\Delta T$ - the temperature change.

The dependence of the specific resistivity of AS and the typical single-crystal n-type conductivity semiconductor (MS) on the radiation dose is shown in Fig. 5. 


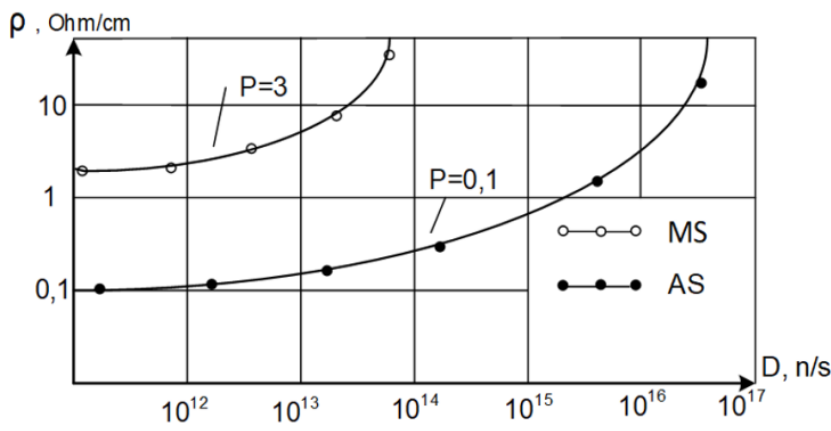

Fig. 5. Dependence of the resistivity of single crystal and amorphous semiconductors on the dose of neutron irradiation

The analysis of the obtained results shows that a significant increase in the specific resistivity of AS occurs at doses 2-3 orders of magnitude larger than in the case of a single-crystal n-type semiconductor.

When irradiated with the same radiation dose, single-crystal semiconductors with higher specific conductivity will significantly increase their own conductivity. For amorphous semiconductors, such a dependence is not observed, that is, different types of chalcogenide glassy semiconductor with different specific conductivities will respond to the same radiation doses approximately the same without significant changes in conductivity. This again proves the feasibility of using CGS as a memory and decoupling element in a thin-film FET.

\section{Conclusions}

1) A memory cell structure is proposed in which a thin-film field-effect transistor based on an amorphous semiconductor is used as a junction element and a switch element based on chalcogenide glassy semiconductor is used as a memory element. Such a structure makes it possible to increase the radiation resistance of storage devices based on such memory cells.

2) A physical model of the memory cell is proposed that takes into account the physical parameters of a thin-film field-effect transistor based on an amorphous semiconductor, the parameters of the switch element, the resistance and the capacitance of the Schottky lines and junctions.

3) The dependence of steepness of the drain-gate characteristics, the recording current of the logical "1" and the gate current on the radiation dose by neutron flux were investigated. Comparisons with similar dependencies for devices based on single-crystal semiconductors show that the use of amorphous semiconductor for the construction of the storage device provides increased radiation resistance.

4) The study of the dependence of the conductivity of singlecrystal semiconductors on the dose of irradiation with neutron flux shows that for amorphous semiconductors, a significant change in conductivity occurs at radiation doses $2-3$ orders of magnitude higher than is needed for a single-crystal n-type conductivity semiconductor. So the influence of penetrating radiation on the parameters of the switch element based on chalcogenide glassy semiconductor is not major.

\section{References}

[1] Belous A. N.: Kosmicheskaya elektronika. Tekhnosfera. Moscow 2015. http://www.itrs.net/ITWG/Beyond_CMOS/2010Memory_April/Proponent/Nano wire\%20PCRAM.pdf.

[2] Jeong K., Ro D., Lee G., Kang M., Lee H.-M.: A Radiation-Hardened Instrumentation Amplifier for Sensor Readout Integrated Circuits in Nuclear Fusion Applications. Electronics 7(12), 2018, 429, [http://doi.org/10.3390/electronics7120429].

[3] Kychak V. M.: Pidvishchenniya radiatsiynoyi stiykosti energonezalezhnykh zapam"iatovuiuchykh prystroyiv na bazi khal'kohenidny sklopodibnykh napivprovidnykiv. Visnyk 4(145), 2019, 116-123.

[4] Kychak V. M.: Vyznachennia pytomoho oporu zapam'iatovuiuchoho prystroiu na bazi khalkohenidnykh sklopodibnykh napivprovidnykiv. Modeliuvannia ta informatsiini tekhnolohii 54, 2009.

[5] Lazar A. P.: Modelirovanie radiotsionnoi stoikosti elementov logicheskikh KMOP integral'nykh mikroskhem. Doklady BGUIR 5(75), 2013.

[6] Mamedov A. K.: Raschet tonkoplenochnыkh tranzystorov s zatvorom Shottki na osnove amorfnoho poluprovodnyka. Tekhnologiya i konstruirovanie $\mathrm{v}$ elektronnoi apparature 2, 2003, 18-21.

[7] Popovich A.: Khal'kogenidnaya energonezavisimaya pamyat' CRAM. Komponenty i tekhnologii 2(103), 2010, 52-54.

[8] Prinzie J., Appels K., Kulis Sz.: Optimal Physical Implementation of Radiation Tolerant High-Speed Digital Integrated Circuits in Deep-Submicron Technologies. Electronics 8(4), 2019, 432, [http://doi.org/10.3390/electronics8040432].

[9] Rajendran B.: Phase change memory technology. IBM Research, 2009.

[10] Van Bockel B., Prinzie J., Leroux P.: Radiation Assessment of a 15.6 ps Single Shot Time-to-Digital Converter in Terms of TID. Electronics 8(5), 2019, 558 , [http://doi.org/10.3390/electronics8050558].

[11] Wong H.-S. P.: Phase Change Memory. Proceedings of the IEEE 98(12), 2010, 2201-2227, [http://doi.org/10.1109/JPROC.2010.2070050]

[12] Zi S.: Fizika poluprovodnikovykh priborov. Mir. Moscow 1984

\section{Prof. Vasyl Kychak}

e-mail: vmkychak@gmail.com

Doctor of Technical Sciences, Professor, Dean of Vinnytsia National Technical University, Honored Worker of Education of Ukraine, Excellence in Education of Ukraine, Academician of the Academy of Engineering Sciences of Ukraine. Author of more than 400 publications, including 15 monographs, 24 textbooks, 29 copyright certificates and patents for inventions and more than 300 scientific articles in professional journals, 21 of them in the Scopus and Web of Science scientometric databases.

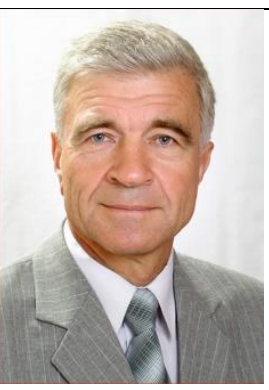

http://orcid.org/0000-0002-1991-9012

Research Assistant Ivan Slobodian

e-mail: ivan.slobodyan.1989@ukr.net

Research Assistant at Department of Telecommunication Systems and TV Broadcasting, Vinnytsia National Technical University. Author of more than 20 publications, including 2 copyright certificates and patents for inventions, 8 scientific articles, 2 of them in the Scopus scientometric database, and more than 10 published abstracts of international conferences.

http://orcid.org/0000-0002-6202-4070

\section{Postgraduate Student Victor Vovk}

e-mail: vovk.v.1@vntu.edu.ua

Postgraduate Student at Department of Telecommunication Systems and TV Broadcasting, Vinnytsia National Technical University. Author of 9 publications, including 4 scientific articles, 1 of them in the Scopus scientometric database, and 5 published abstracts of international conferences. 